\title{
Melatonin reduces inflammation and recovers endogenous ghrelin in acute necrotizing pancreatitis in rats
}

\author{
ZHI-HAI LIANG, MENG-BIN QIN, GUO-DU TANG, HUI-YING YANG, JUAN SU and JIE-AN HUANG
}

Department of Gastroenterology, First Affiliated Hospital of Guangxi Medical University, Nanning, Guangxi 530021, P.R. China

Received August 23, 2013; Accepted March 12, 2014

DOI: $10.3892 / \mathrm{mmr} .2014 .2132$

\begin{abstract}
The present study aimed to evaluate the therapeutic effects of melatonin on either ghrelin secretion or gastric mucosal injury in acute necrotizing pancreatitis (ANP). ANP was induced in rats by L-arginine. Prior to L-arginine injection, the rats were pre-treated with melatonin for $30 \mathrm{~min}$. Following the last injection, the animals were sacrificed at different time-points. The levels of ghrelin and melatonin in the serum and gastric tissue were detected by ELISA. Levels of tumor necrosis factor (TNF)- $\alpha$, interleukin (IL)- 6 and malondialdehyde (MDA) as well as total superoxide dismutase (T-SOD) activities in gastric tissue were measured. In rats with ANP, acute gastric injury was observed, and the levels of MDA, SOD, TNF- $\alpha$ and IL- 6 were significantly increased. The melatonin levels in serum or gastric tissue peaked at $6 \mathrm{~h}$ and returned to normal levels at $12 \mathrm{~h}$ after melatonin was administered. However, ghrelin remained at low levels during the first $12 \mathrm{~h}$, but it recovered at $24 \mathrm{~h}$ and continued increasing, while the levels of oxidative stress damage and activity of inflammatory factors were decreased. The protective effects of melatonin on acute gastric injury during the early stages of ANP may be mediated through anti-oxidative and anti-inflammatory activities, while at advanced stages of ANP, it may be mediated through the recovered endogenous ghrelin.
\end{abstract}

\section{Introduction}

Severe acute pancreatitis (SAP) is an inflammatory disease of the pancreas associated with high morbidity and mortality rates, as well as multiple organ dysfunction $(1,2)$. The precise mechanisms underlying the promotion of local inflammation in the pancreas to systemic illness remain to be fully elucidated, although various theories of self-digestion, leukocyte

Correspondence to: Professor Guo-Du Tang, Department of Gastroenterology, First Affiliated Hospital of Guangxi Medical University, 6 Shuangyong Road, Nanning, Guangxi 530021, P.R. China

E-mail: tguodu02@163.com

Key words: ghrelin, acute necrotizing pancreatitis, acute gastric injury, melatonin, oxidative damage over-activation, microcirculatory disorder, bacterial shifting and secondary infection, immune functional change, cell apoptosis and oxygen free radicals have explained the pathogenesis of SAP from different angles (3). The systemic inflammatory response syndrome, associated with the failure of distant organ systems, including the lungs, stomach, intestine and kidneys (4-6), has become a widely accepted disease state. A previous study revealed that acute gastrointestinal mucosal lesions (AGMLs) were associated with SAP and that acid-suppressive therapy was a necessary treatment (7). It is thought that oxidative damage and over-activation of inflammatory factors have a significant role during the pathogenesis of acute necrotizing pancreatitis (ANP) in gastric mucosal injury (8).

Although melatonin is best known as a pineal product, a study had revealed that the gastrointestinal tract is the main source for the production of melatonin in the organism (9). The most conspicuous value of melatonin lies in its anti-oxidative properties, since it acts not only as a reactive oxygen species (ROS) scavenger, but also as an activator of the anti-oxidative enzyme system (10). Treatment with melatonin could attenuate gastric injury induced by ischemia/reperfusion (11), oxygen radicals, ethanol (12) and acid (13).

Ghrelin, a novel growth hormone $(\mathrm{GH})$-releasing peptide that was initially isolated from gastric X/A-like cells, is a natural ligand for GH secretagogue receptor (GHS-R) (14). It has been reported that endogenous ghrelin revealed multiple, strong gastro-protective functions, including preventing mitigated gastric mucosal lesion, increasing gastric mucosal blood flow (GMBF) and luminal nitric oxide (NO) concentration $(15,16)$, inhibiting neutrophil infiltration (17), promoting transforming growth factor-1 released from gastrointestinal mucosa cells (18) and reducing nitric oxide synthase (NOS) expression induced by gastric ischemic injury and ROS generation induced by human polymorphonuclear leukocytes (19).

Although melatonin and ghrelin demonstrate similar effects of anti-oxidation and anti-inflammation and act as potent preventive factors for gastric injury, the association of exogenous melatonin and endogenous ghrelin in acute gastric injury induced by severe systemic disease, including SAP, remains unknown. In order to analyze the synergistic effects of melatonin and ghrelin in the prevention of acute gastric injury, the levels of ghrelin and the inflammatory cytokines in the serum and gastric tissue of rats with ANP were examined and the efficacy of melatonin pretreatment for oxidative injury of gastric tissue in ANP was evaluated. 


\section{Materials and methods}

Animals and experimental design. A total of 120 adult male Sprague-Dawley rats (weighing 250-300 g) were provided by the Laboratory Animal Center of Guangxi Medical University (Guangxi Medical University, Nanning, Guangxi, China). The animals were housed in cages at normal room temperature and in a light-controlled room (12-h light/dark cycle). The animals were fed standard food and water. All the rats for the experiments were kept for at least one week for adaptation prior to the beginning of the experimental procedure. The rats were fasted for $16 \mathrm{~h}$ prior to the injections, while access to water was maintained until they were sacrificed.

Three experimental groups were established: 1) control (group C, n=40): Animals were injected with saline intraperitoneally (i.p); 2) ANP (group A, n=40): ANP was induced by i.p. injection of $500 \mathrm{mg} / 100 \mathrm{~g}$ L-arginine (Sigma-Aldrich Corp., St. Louis, MO, USA); 3) melatonin treatment (group M, n=40): Melatonin (5 $\mu \mathrm{g} / 100 \mathrm{~g}$ ) (Sigma-Aldrich Corp.) was administered by i.p. injection $30 \mathrm{~min}$ prior to L-arginine injection. All the rats were permitted to take water and food following the experiment. Food intake was ceased $2 \mathrm{~h}$ prior to the sacrifice. In total, eight animals per group were sacrificed under anesthesia at $6,12,24,48$ and $72 \mathrm{~h}$ after the last injection. Blood samples were collected from the abdominal aorta for measurements. The tissues of the pancreas and stomach were obtained immediately following blood withdrawal and fixed in formalin solution for $24 \mathrm{~h}$, followed by paraffin embedding and sectioning for routine histopathological analysis. Gastric tissues were extracted and rinsed with saline for detection of ghrelin and inflammatory factors, as well as for the measurement of oxidative stress injury levels. The present study was approved by the Ethics Committee of the First Affiliated Hospital of Guangxi Medical University (Nanning, Guangxi, China).

Pathological scores of pancreatic and gastric tissues. The pancreatic and gastric tissues were excised and fixed in 10\% formalin and embedded in paraffin. For pathological observation, the sections were cut and stained with hemotoxylin and eosin. A double-blind microscopic analysis was performed by two senior pathologists. Pathological score for pancreatic tissues on a scale from 0 to 4 were determined in regard to the degree of edema, inflammation, hemorrhage and necrosis, according to the method described by Kusske et al (20). The score for stomach damage was evaluated according to criteria proposed by Lo et al (21).

Detection of melatonin, ghrelin, tumor necrosis factor (TNF)- $\alpha$ and interleukin (IL)- 6 by ELISA. The levels of melatonin, ghrelin, TNF- $\alpha$ and IL- 6 in gastric tissue were determined using a commercially available ELISA kits (BD Biosciences, Franklin Lakes, NJ, USA). The serum levels of melatonin and ghrelin were measured using the ELISA method.

Measurement of total superoxide dismutase (T-SOD) activity in gastric tissue. Gastric samples were prepared as described above. The activities of T-SOD in homogenized tissues were determined using an assay kit (Nanjing Jiancheng Corp.,
Nanjing, Jiangsu, China) according to the manufacturer's instructions. The measurement of T-SOD activity was based on the generation of superoxide radicals produced by xanthine and xanthine oxidase, which reacts with 2-(4-iodophenyl)-3 -(4-nitrophenol)-5-phenyl tetrazolium chloride to form a red formazan dye. The reaction results were read at $550 \mathrm{~nm}$ and T-SOD activity was expressed as units per milligram protein (U/mg protein).

Estimation of malondialdehyde (MDA) content in the stomach. Gastric tissues were dissected out and rinsed immediately with ice cold saline to remove as much blood as possible. Gastric tissue homogenates $(5 \% \mathrm{w} / \mathrm{v})$ were prepared in ice with cold $50 \mathrm{mM}$ potassium phosphate buffer ( $\mathrm{pH}$ 7.4) using a glass homogenizer followed by centrifugation at $3,000 \mathrm{~g}$ for $10 \mathrm{~min}$ at $4^{\circ} \mathrm{C}$. Finally, the supernatants were decanted for the measurement. The protein concentrations were determined by the Lowry method. The MDA content in the supernatant was determined according to a reading at 532 $\mathrm{nm}$ of the thiobarbituric acid-reactive substances (22), using an assay kit (Nanjing Jiancheng Corp., Nanjing, Jiangsu, China) following the manufacturer's instructions. The MDA content was expressed as nanomole per milligram protein (nmol/mg protein).

Statistical analyses. Values are expressed as the mean \pm standard deviation. SPSS for windows version 13.0 (SPSS, Inc., Chicago, IL, USA) was used for statistical analysis. Differences between groups were analyzed by one-way analysis of variance. $\mathrm{P}<0.05$ was used to indicate a statistically significant difference.

\section{Results}

Pathological damages in pancreatic and gastric tissues. The gross pathological changes were observed in rats with ANP, including hemorrhagic ascites, necrosis foci in the pancreas and several saponifying spots in the mesentery and greater omentum, as well as the infiltrating inflammatory cells in the pancreatic stroma and glandular lobule. In addition, diffuse bleeding and necrosis were observed. The pathological changes were exacerbated in rats with ANP as time passed. However, in the melatonin treatment group, less necrosis foci were present in the pancreas and the occurrence of hemorrhagic ascites was not found. In addition, saponifying spots were not observed in the mesentery and greater omentum. In the melatonin treatment group, although inflammatory cells infiltrating the pancreatic stroma and glandular lobule were observed, diffuse bleeding and piecemeal necrosis did not appear in the pancreas. The scores in group A and M significantly increased at each time-point compared with those in group $\mathrm{C}(\mathrm{P}<0.05)$. However, the scores in group $\mathrm{M}$ significantly decreased at each time-point compared with those in group $\mathrm{A}(\mathrm{P}<0.05)$ (Table I).

In the rats with ANP (group A), mucosal swelling and distension, scattered bleeding points and anabrosis were present in the body of the stomach. Under an optical microscope, engorgement, hemorrhage, edema, anabrosis and gastric glandular mucosa were observed, but neither deep ulcers nor necrosis was found. The pathological changes in 
Table I. Scores of pancreatic pathological damage.

\begin{tabular}{llllll}
\hline Group & $6 \mathrm{~h}$ & $12 \mathrm{~h}$ & $24 \mathrm{~h}$ & $48 \mathrm{~h}$ & $72 \mathrm{~h}$ \\
\hline $\mathrm{C}$ & $0.14 \pm 0.17$ & $0.14 \pm 0.18$ & $0.20 \pm 0.15$ & $0.23 \pm 0.11$ & $0.21 \pm 0.13$ \\
$\mathrm{~A}$ & $4.15 \pm 1.09^{\mathrm{a}}$ & $5.35 \pm 0.89^{\mathrm{a}}$ & $8.34 \pm 0.98^{\mathrm{a}}$ & $9.15 \pm 1.15^{\mathrm{a}}$ & $10.52 \pm 1.28^{\mathrm{a}}$ \\
$\mathrm{M}$ & $1.82 \pm 0.55^{\mathrm{a}, \mathrm{b}}$ & $2.27 \pm 1.08^{\mathrm{a}, \mathrm{b}}$ & $6.37 \pm 0.56^{\mathrm{a}, \mathrm{b}}$ & $7.11 \pm 0.87^{\mathrm{a}, \mathrm{b}}$ & $7.52 \pm 1.03^{\mathrm{a}, \mathrm{b}}$ \\
\hline
\end{tabular}

Pathological score for pancreatic tissues on a scale from 0 to 4 were determined according to the degree of edema, inflammation, hemorrhage and necrosis, respectively, according to the method described previously (20). The pathological score for each animal is presented as the sum of the edema, inflammation, hemorrhage and necrosis scores. ${ }^{\mathrm{P}} \mathrm{P}<0.05$ vs. group $\mathrm{C}$; ${ }^{\mathrm{b}} \mathrm{P}<0.05$ vs. group $\mathrm{A}$. $\mathrm{C}$, control group; A, acute necrotizing pancreatitis induced by L-arginine group; $\mathrm{M}$, melatonin-treated prior to L-arginine injection group.

Table II. Scores of gastric pathological damage.

\begin{tabular}{|c|c|c|c|c|c|}
\hline Group & $6 \mathrm{~h}$ & $12 \mathrm{~h}$ & $24 \mathrm{~h}$ & $48 \mathrm{~h}$ & $72 \mathrm{~h}$ \\
\hline $\mathrm{C}$ & $1.88 \pm 0.64$ & $1.88 \pm 0.83$ & $2.25 \pm 0.71$ & $2.00 \pm 0.76$ & $1.88 \pm 0.64$ \\
\hline A & $8.75 \pm 1.04^{\mathrm{a}}$ & $8.88 \pm 1.25^{\mathrm{a}}$ & $9.63 \pm 1.06^{\mathrm{a}}$ & $9.75 \pm 1.16^{\mathrm{a}}$ & $9.38 \pm 1.41^{\mathrm{a}}$ \\
\hline M & $5.50 \pm 0.93^{\mathrm{a}, \mathrm{b}}$ & $6.38 \pm 1.19^{\mathrm{a}, \mathrm{b}}$ & $6.88 \pm 1.36^{\mathrm{a}, \mathrm{b}}$ & $5.63 \pm 1.06^{\mathrm{a}, \mathrm{b}}$ & $6.25 \pm 1.04^{\mathrm{a}, \mathrm{b}}$ \\
\hline
\end{tabular}

${ }^{a} \mathrm{P}<0.05$ vs. group $\mathrm{C}$ and ${ }^{\mathrm{b}} \mathrm{P}<0.05$ vs. group A. C, control group; A, acute necrotizing pancreatitis induced by L-arginine group; M, melatonin-treated prior to L-arginine injection group.

Table III. Levels of ghrelin in serum and stomach.

\begin{tabular}{|c|c|c|c|c|c|}
\hline Group & $6 \mathrm{~h}$ & $12 \mathrm{~h}$ & $24 \mathrm{~h}$ & $48 \mathrm{~h}$ & $72 \mathrm{~h}$ \\
\hline \multicolumn{6}{|c|}{ Serum ghrelin (ng/ml) } \\
\hline $\mathrm{C}$ & $4.35 \pm 0.90$ & $4.26 \pm 1.26$ & $4.36 \pm 1.14$ & $4.07 \pm 1.10$ & $4.67 \pm 1.12$ \\
\hline A & $1.18 \pm 0.27^{\mathrm{a}}$ & $0.76 \pm 0.24^{\mathrm{a}}$ & $0.77 \pm 0.22^{\mathrm{a}}$ & $0.78 \pm 0.19^{a}$ & $0.80 \pm 0.16^{\mathrm{a}}$ \\
\hline M & $1.35 \pm 0.43^{\mathrm{a}, \mathrm{b}}$ & $3.19 \pm 0.66^{\mathrm{a}, \mathrm{b}}$ & $4.01 \pm 1.22^{b}$ & $6.82 \pm 0.86^{\mathrm{a}, \mathrm{b}}$ & $8.15 \pm 0.79^{a, b}$ \\
\hline \multicolumn{6}{|c|}{ Stomach ghrelin $(\mathrm{ng} / \mathrm{ml})$} \\
\hline $\mathrm{C}$ & $5.84 \pm 0.64$ & $5.86 \pm 0.81$ & $5.59 \pm 0.63$ & $5.78 \pm 0.77$ & $5.68 \pm 0.56$ \\
\hline A & $1.12 \pm 1.04^{\mathrm{a}}$ & $0.75 \pm 0.22^{\mathrm{a}}$ & $0.72 \pm 0.18^{\mathrm{a}}$ & $0.73 \pm 0.19^{a}$ & $0.73 \pm 0.19^{a}$ \\
\hline M & $2.15 \pm 0.93^{\mathrm{a}, \mathrm{b}}$ & $3.71 \pm 0.50^{\mathrm{a}, \mathrm{b}}$ & $5.25 \pm 0.81^{\mathrm{b}}$ & $8.17 \pm 0.79^{\mathrm{a}, \mathrm{b}}$ & $9.75 \pm 0.78^{a, b}$ \\
\hline
\end{tabular}

${ }^{a} \mathrm{P}<0.05$ vs. group $\mathrm{C}$ and ${ }^{\mathrm{b}} \mathrm{P}<0.05$ vs. group A. C, control group; A, acute necrotizing pancreatitis induced by L-arginine group; M, melatonin-treated prior to L-arginine injection group.

group $\mathrm{M}$ were less serious than those in group A. Although mucosal swelling and distension in the body of the stomach and gastric glandular mucosa were still observed in group $\mathbf{M}$, hemorrhage, edema and anabrosis disappeared. The scores in group $\mathrm{A}$ and $\mathrm{M}$ significantly increased at each time-point compared with those in group $\mathrm{C}(\mathrm{P}<0.05)$; however, the scores in group $\mathrm{M}$ significantly decreased at each time-point compared with those in group A $(\mathrm{P}<0.05)$ (Table II).

Levels of ghrelin and melatonin in serum and stomach. The levels of ghrelin in the serum and stomach were significantly decreased in group A at each time-point compared with those in group $\mathrm{C}(\mathrm{P}<0.05)$. The levels of ghrelin in serum and in gastric tissue in group $\mathrm{M}$ were lower compared with that in group $\mathrm{C}$ during the early stages $(6$ and $12 \mathrm{~h})(\mathrm{P}<0.05)$; however, its concentration at $24 \mathrm{~h}$ reverted to similar levels in group $\mathrm{C}(\mathrm{P}>0.05)$ and kept increasing beyond $24 \mathrm{~h}(\mathrm{P}<0.05$, compared with group C) (Table III, Fig. 1A and B). The endogenous melatonin in serum and stomach was at low levels in group A at all time-points compared with that in group $\mathrm{C}(\mathrm{P}<0.05)$. In group $\mathrm{M}$, the levels of melatonin reached a peak at $6 \mathrm{~h}$ after the last injection $(\mathrm{P}<0.05$ vs. group $\mathrm{C})$, then rapidly returned to normal levels at $12 \mathrm{~h}$. At later stages, there was no significant difference between groups $\mathrm{M}$ and $\mathrm{C}$ (P>0.05) (Table IV, Fig. 2A and B).

Levels of inflammatory cytokines in the stomach. Since the levels of TNF- $\alpha$ and IL- 6 reflect the severity of inflammation in the stomach, the concentrations of TNF- $\alpha$ and IL-6 in homogenized gastric tissues was measured. The level of TNF- $\alpha$ in group A was significantly higher compared with that in group $\mathrm{C}$ at all time-points $(\mathrm{P}<0.05)$. In group $\mathrm{M}$, the 
Table IV. Levels of melatonin in serum and stomach.

\begin{tabular}{|c|c|c|c|c|c|}
\hline Group & $6 \mathrm{~h}$ & $12 \mathrm{~h}$ & $24 \mathrm{~h}$ & $48 \mathrm{~h}$ & $72 \mathrm{~h}$ \\
\hline \multicolumn{6}{|c|}{ Serum melatonin (pg/ml) } \\
\hline $\mathrm{C}$ & $283.07 \pm 37.77$ & $293.20 \pm 37.15$ & $290.31 \pm 27.49$ & $292.13 \pm 34.74$ & $299.31 \pm 34.34$ \\
\hline A & $205.86 \pm 28.96^{\mathrm{a}}$ & $158.64 \pm 18.18^{\mathrm{a}}$ & $136.88 \pm 21.59^{a}$ & $133.96 \pm 29.14^{\mathrm{a}}$ & $143.35 \pm 30.55^{\mathrm{a}}$ \\
\hline M & $870.99 \pm 101.59^{a, b}$ & $327.31 \pm 280.94^{b}$ & $280.94 \pm 30.85^{b}$ & $287.84 \pm 26.83^{b}$ & $284.84 \pm 26.69^{b}$ \\
\hline \multicolumn{6}{|c|}{ Stomach melatonin $(\mathrm{pg} / \mathrm{ml})$} \\
\hline $\mathrm{C}$ & $337 \pm 29.78$ & $325.05 \pm 43.67$ & $325.01 \pm 46.23$ & $317.87 \pm 46.50$ & $330.89 \pm 44.50$ \\
\hline A & $225.26 \pm 36.50^{\mathrm{a}}$ & $212.98 \pm 41.72^{\mathrm{a}}$ & $214.67 \pm 44.57^{\mathrm{a}}$ & $198.10 \pm 35.50^{\mathrm{a}}$ & $211.40 \pm 29.52^{\mathrm{a}}$ \\
\hline M & $917.41 \pm 78.46^{\mathrm{a}, \mathrm{b}}$ & $323.29 \pm 39.07^{\mathrm{b}}$ & $302.41 \pm 28.06^{\mathrm{b}}$ & $297.21 \pm 29.21^{\mathrm{b}}$ & $303.84 \pm 38.61^{\mathrm{b}}$ \\
\hline
\end{tabular}

${ }^{\mathrm{a}} \mathrm{P}<0.05$ vs. group $\mathrm{C}$ and ${ }^{\mathrm{b}} \mathrm{P}<0.05$ vs. group A. C, control group; A, acute necrotizing pancreatitis induced by L-arginine group; M, melatonin-treated prior to L-arginine injection group.

A

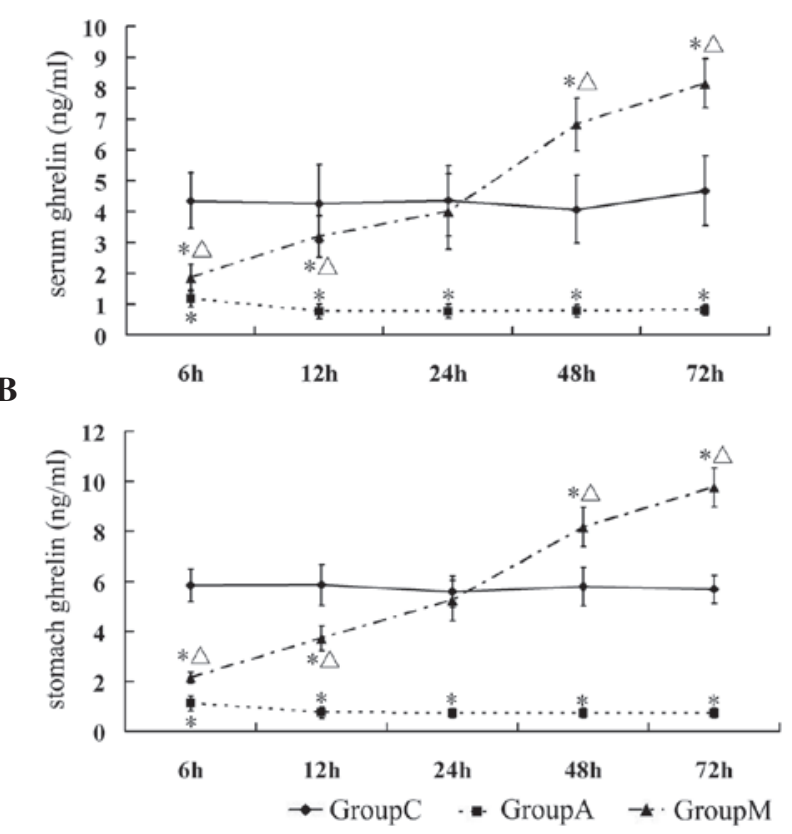

Figure 1. Levels of ghrelin in serum and stomach were significantly decreased in rats with ANP. (A) The levels of ghrelin in serum were detected by ELISA at the indicated time-points in group C (diamond), group A (square) and group $\mathrm{M}$ (triangle). (B) The levels of ghrelin in gastric tissue were detected by ELISA at the indicated time-points in group $\mathrm{C}$ (diamond), group $\mathrm{A}$ (square) and group $\mathrm{M}$ (triangle). ${ }^{*} \mathrm{P}<0.05$, compared with group $\mathrm{C} ;{ }^{\stackrel{ }{ } \mathrm{P}<0.05}$ compared with group $\mathrm{A}$. ANP, acute necrotizing pancreatitis; $\mathrm{C}$, control group; A, ANP induced by $\mathrm{L}$-arginine group; $\mathrm{M}$, melatonin-treated prior to L-arginine injection group.

levels of TNF- $\alpha$ were consistently lower compared with those in group $\mathrm{A}$ at each time-point, but remained higher compared with those in group $\mathrm{C}(\mathrm{P}<0.05)$ (Table V, Fig. 3A). A similar result was also observed for IL-6 ( $<<0.05$ vs. group $\mathrm{C})$ (Table V, Fig. 3B).

Severity of oxidative injury in the stomach. T-SOD, which catalyzes the dismutation of the superoxide anion into hydrogen peroxide and molecular oxygen, is one of the most significant anti-oxidative enzymes. MDA, the major product of lipid peroxidation, is considered to be an indicator of mucosal injury by ROS. In the present study, T-SOD
A
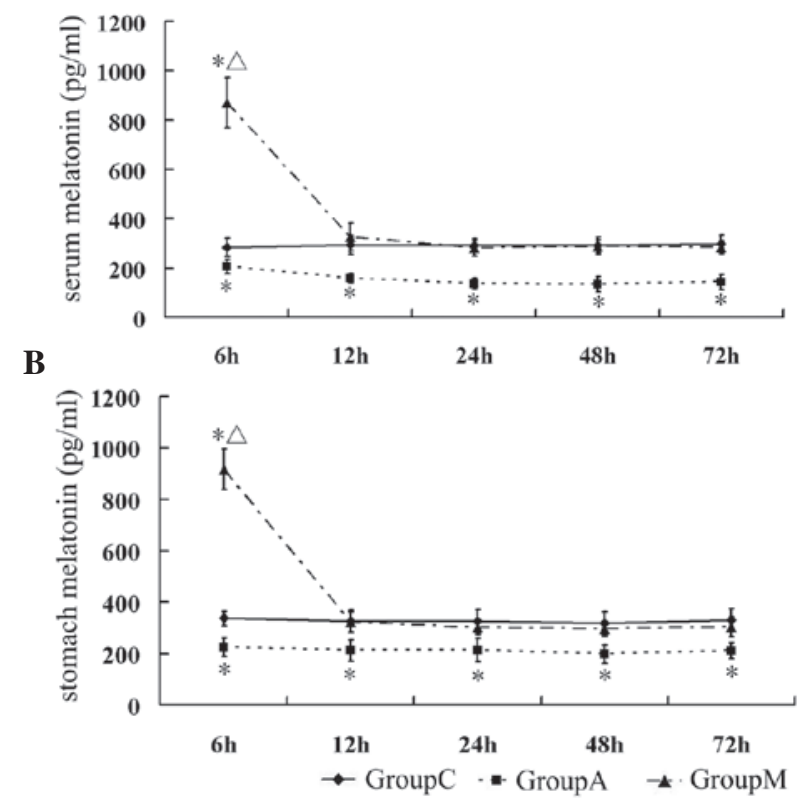

Figure 2. Levels of melatonin in the serum and stomach of the experimental animals. (A) The levels of melatonin in the serum were detected by ELISA at the indicated time-points in group C (diamond), group A (square) and group $\mathrm{M}$ (triangle). (B) The levels of melatonin in the stomach were detected by ELISA at the indicated time-points in group C (diamond), group A (square) and group $\mathrm{M}$ (triangle). ${ }^{*} \mathrm{P}<0.05$, compared with group $\mathrm{C}$; ${ }^{\Delta} \mathrm{P}<0.05$ compared with group A. C, control group; A, acute necrotizing pancreatitis induced by L-arginine group; M, melatonin-treated prior to L-arginine injection group. and MDA were assessed and regarded as indicators of oxidative injury in the stomach. The results revealed that T-SOD activity in the stomach was downregulated at each time-point in group A (ANP) $(\mathrm{P}<0.05$ vs. group C), but its activity was partially retained in the melatonin treatment group (group $\mathrm{M})$ compared with that in group $\mathrm{A}(\mathrm{P}<0.05)$ (Table VI, Fig. 4A). MDA levels were low in normal gastric mucus and were significantly increased at all time-points in the stomach of rats with ANP (group A) ( $\mathrm{P}<0.05$ vs. group C). Melatonin treatment significantly reduced the levels of MDA at all time-points in group M, compared with that of group A $(\mathrm{P}<0.05)$ (Table VI, Fig. 4B). 
Table V. Levels of inflammatory factors in stomach.

\begin{tabular}{|c|c|c|c|c|c|}
\hline Group & $6 \mathrm{~h}$ & $12 \mathrm{~h}$ & $24 \mathrm{~h}$ & $48 \mathrm{~h}$ & $72 \mathrm{~h}$ \\
\hline \multicolumn{6}{|c|}{ Stomach TNF- $\alpha(\mathrm{pg} / \mathrm{ml})$} \\
\hline $\mathrm{C}$ & $3.27 \pm 0.63$ & $3.06 \pm 0.35$ & $3.03 \pm 0.35$ & $3.06 \pm 0.39$ & $3.02 \pm 0.36$ \\
\hline A & $17.84 \pm 1.38^{\mathrm{a}}$ & $26.58 \pm 3.78^{a}$ & $38.84 \pm 4.59^{\mathrm{a}}$ & $40.22 \pm 3.33^{\mathrm{a}}$ & $41.84 \pm 5.72^{\mathrm{a}}$ \\
\hline $\mathrm{M}$ & $10.40 \pm 1.43^{a . b}$ & $11.17 \pm 1.79^{\mathrm{a}, \mathrm{b}}$ & $10.93 \pm 1.83^{\mathrm{a}, \mathrm{b}}$ & $11.07 \pm 1.71^{\mathrm{a}, \mathrm{b}}$ & $10.82 \pm 0.60^{\mathrm{a}, \mathrm{b}}$ \\
\hline \multicolumn{6}{|c|}{ Stomach IL-6 (pg/ml) } \\
\hline $\mathrm{C}$ & $86.83 \pm 13.95$ & $89.13 \pm 16.93$ & $87.78 \pm 14.68$ & $89.75 \pm 8.62$ & $88.36 \pm 12.43$ \\
\hline A & $206.07 \pm 17.90^{\mathrm{a}}$ & $265.25 \pm 20.49^{\mathrm{a}}$ & $312.63 \pm 24.05^{\mathrm{a}}$ & $387.81 \pm 35.75^{\mathrm{a}}$ & $451.01 \pm 33.74^{\mathrm{a}}$ \\
\hline M & $164.32 \pm 18.78^{\mathrm{a}, \mathrm{b}}$ & $193.17 \pm 17.46^{\mathrm{a}, \mathrm{b}}$ & $232.35 \pm 25.59^{\mathrm{a}, \mathrm{b}}$ & $232.89 \pm 30.70^{\mathrm{a}, \mathrm{b}}$ & $226.32 \pm 31.77^{\mathrm{a}, \mathrm{b}}$ \\
\hline
\end{tabular}

${ }^{\mathrm{a}} \mathrm{P}<0.05$ vs. group $\mathrm{C}$ and ${ }^{\mathrm{b}} \mathrm{P}<0.05$ vs. group $\mathrm{A}$. TNF- $\alpha$, tumor necrosis factor $\alpha$; IL-6, interleukin-6. C, control group; A, acute necrotizing pancreatitis induced by L-arginine group; $\mathrm{M}$, melatonin-treated prior to L-arginine injection group.

A

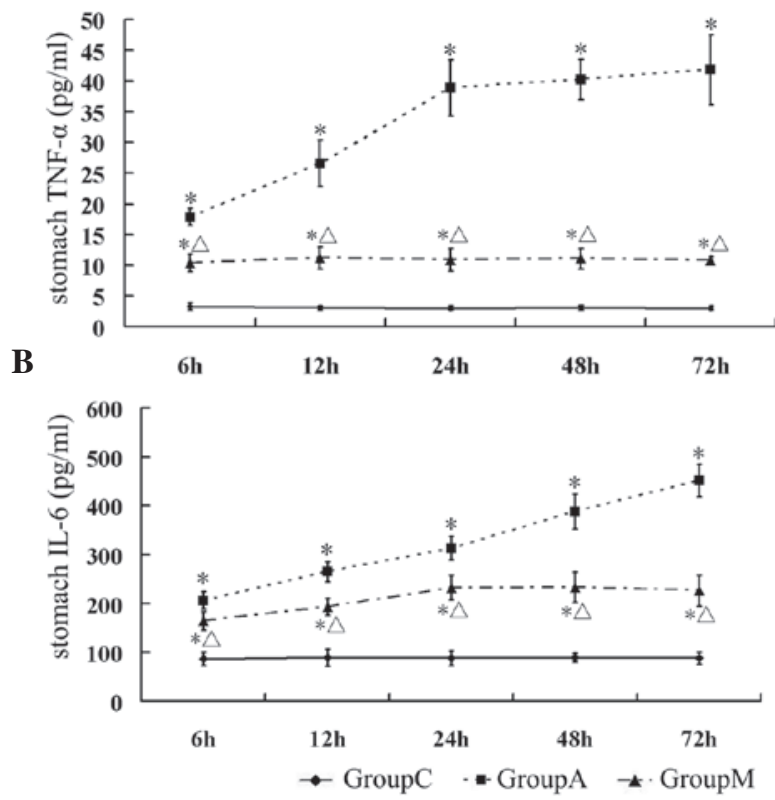

Figure 3. Levels of inflammatory factors in the stomach of experimental animals. (A) The levels of TNF- $\alpha$ in the stomach were detected by ELISA at the indicated time-points in group $\mathrm{C}$ (diamond), group A (square) and group M (triangle). (B) The levels of IL-6 in the stomach were detected by ELISA at the indicated time-points in group $\mathrm{C}$ (diamond), group A (square) and group $\mathrm{M}$ (triangle). ${ }^{*} \mathrm{P}<0.05$, compared with group $\mathrm{C} ;{ }^{\Delta} \mathrm{P}<0.05$, compared with group A. TNF- $\alpha$, tumor necrosis factor $\alpha$; IL-6, interleukin-6; C, control group; A, acute necrotizing pancreatitis induced by L-arginine group; $\mathrm{M}$, melatonin-treated prior to L-arginine injection group.

\section{Discussion}

The main findings of the present study were that: a) Acute gastric injury was present in a rat model of ANP, which correlated with oxidative stress and inflammatory factors. The damage of ANP was reduced in the melatonin-treated animals, through anti-oxidative and anti-inflammatory effects. b) Melatonin pretreatment improved the ghrelin levels in serum and stomach in response to gastric tissue injury during the early stage of ANP. c) Endogenous ghrelin has a lasting anti-oxidative and anti-inflammatory effect and the production of endogenous melatonin was inhibited in a rat model of ANP.
A

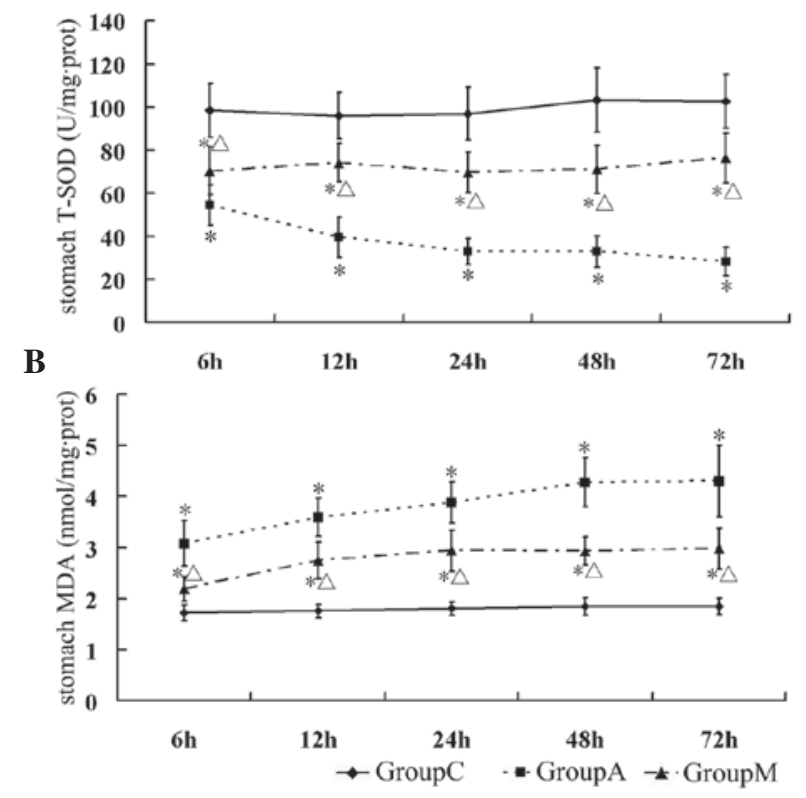

Figure 4. Measurement of the severity of oxidative injury in the stomach of the experimental animals. (A) T-SOD activity in the stomach was measured at the indicated time-points in group $\mathrm{C}$ (diamond), group A (square) and group M (triangle). (B) MDA content in the stomach was measured at all the time-points in group $\mathrm{C}$ (diamond), group A (square) and group M (triangle). ${ }^{*} \mathrm{P}<0.05$, compared with group $\mathrm{C} ;{ }^{\Delta} \mathrm{P}<0.05$, compared with group $\mathrm{A}$. MDA, malondialdehyde; T-SOD, total superoxide dismutase; C, control group; A, acute necrotizing pancreatitis induced by L-arginine group; $\mathrm{M}$, melatonin-treated prior to L-arginine injection group.

It is generally hypothesized that trypsin and other pancreatic enzymes are activated and released in acute pancreatitis, leading to pancreatitis-associated multiple organ dysfunction syndrome involving vital organs, including the heart, brain, kidney, liver, intestine and stomach. AGML can be induced by a stress reaction and inflammatory factors released from immunocompetent cells. It was reported that AGML occurred in $65 \%$ of patients with acute pancreatitis (7). In animal experiments, treatment with sodium taurocholate for $2 \mathrm{~h}$ significantly reduced GMBF in a rat model of ANP, while the levels of IL-1 $\beta$ and MPO in the gastric mucosa were significantly increased (4). The present study found that the exulceration 
Table VI. Severity of oxidative injury in the stomach.

\begin{tabular}{lccccc}
\hline Group & $6 \mathrm{~h}$ & $12 \mathrm{~h}$ & $24 \mathrm{~h}$ & $48 \mathrm{~h}$ & $72 \mathrm{~h}$ \\
\hline Stomach T-SOD activity (U/mg protein) & & & & & \\
C & $98.45 \pm 12.39$ & $96.02 \pm 10.83$ & $96.91 \pm 12.04$ & $103.28 \pm 14.80$ & $102.61 \pm 12.60$ \\
A & $54.62 \pm 9.34^{\mathrm{a}}$ & $39.73 \pm 9.27^{\mathrm{a}}$ & $32.86 \pm 6.08^{\mathrm{a}}$ & $32.95 \pm 7.22^{\mathrm{a}}$ & $28.39 \pm 6.68^{\mathrm{a}}$ \\
M & $70.43 \pm 11.06^{\mathrm{a}, \mathrm{b}}$ & $74.20 \pm 8.95^{\mathrm{a}, \mathrm{b}}$ & $69.73 \pm 9.29^{\mathrm{a}, \mathrm{b}}$ & $71.11 \pm 11.27^{\mathrm{a}, \mathrm{b}}$ & $76.29 \pm 11.46^{\mathrm{a}, \mathrm{b}}$ \\
Stomach MDA (nmol/mg protein) & & & & \\
C & $1.72 \pm 0.15$ & $1.76 \pm 0.13$ & $1.81 \pm 0.13$ & $1.85 \pm 0.17$ & $1.85 \pm 0.16$ \\
A & $3.08 \pm 0.44^{\mathrm{a}}$ & $3.59 \pm 0.38^{\mathrm{a}}$ & $3.88 \pm 0.41^{\mathrm{a}}$ & $4.27 \pm 0.48^{\mathrm{a}}$ & $4.30 \pm 0.70^{\mathrm{a}}$ \\
M & $2.19 \pm 0.24^{\mathrm{a}, \mathrm{b}}$ & $2.75 \pm 0.36^{\mathrm{a}, \mathrm{b}}$ & $2.94 \pm 0.40^{\mathrm{a}, \mathrm{b}}$ & $2.93 \pm 0.27^{\mathrm{a}, \mathrm{b}}$ & $2.98 \pm 0.40^{\mathrm{a}, \mathrm{b}}$
\end{tabular}

${ }^{\text {a }} \mathrm{P}<0.05$ vs. group $\mathrm{C}$ and ${ }^{\mathrm{b}} \mathrm{P}<0.05$ vs. group $\mathrm{A}$. MDA, malondialdehyde; T-SOD, total superoxide dismutase.

simplex occurred in the stomachs of rats with ANP, but deep ulcers or necrosis were not observed. The course of acute gastric injury reached a peak during the first $24 \mathrm{~h}$ and lasted for $72 \mathrm{~h}$ after formation of ANP. Similar to the progress of the gastric injury, the levels of MDA and SOD, an indicator for the severity of oxidative stress, and the levels of TNF- $\alpha$ and IL-6, an indicator for the activity of inflammatory factors, were significantly increased from 6 to $72 \mathrm{~h}$ after formation of ANP. It has been implicated that acute gastric injury is associated with oxidative stress damage and activation of inflammatory factors in ANP. Endogenous melatonin comes mainly from the gastrointestinal tract $(9,23)$. Melatonin is considered a highly effective tissue protector due to its ability to scavenge ROS (10,24). Since melatonin has anti-inflammatory and anti-oxidant properties, this may be one of the most efficient protective factors in preventing the development of acute gastric damage and accelerate the healing of chronic gastric ulcers, possibly through mechanisms underlying reduction of pro-inflammatory cytokine production, scavenging of ROS and activation of cyclooxygenase-prostaglandins (COX-PG) and NOS-NO systems (25). Under physiological conditions, the half-life of melatonin has been reported to be $\sim 23 \mathrm{~min}$ in rat plasma (26). In the present study, rats received a single melatonin administration prior to L-arginine injection and the highest levels of melatonin in the serum or gastric tissue were observed at $6 \mathrm{~h}$ following formation of ANP. Furthermore, the concentration of melatonin, either in circulation or in gastric tissues, returned to normal levels at $12 \mathrm{~h}$ after formation of ANP. However, the oxidative stress damage and activity of inflammatory factors decreased over time. These data indicated that the anti-oxidation and anti-inflammatory effects of exogenous melatonin occurred during early stages of acute gastric injury in rats with ANP and its protective effect during later stages are likely to be mediated through other auto-protective factors, including ghrelin, which is induced by melatonin. Ghrelin has potential biological functions, including gastro-protective and hyperemic activities against ischemia/reperfusion-induced erosion, as well as effects that are mediated by hormonal activation of GHS-R1a receptors, the COX-PG system and vagal-sensory nerves (27). Ghrelin was found to reduce stress-mediated gastric injury, including ethanol-induced gastric injury (28-31), acetic acid-induced chronic gastric ulcers and ischemia/reperfusion-induced gastric injury (19).
These effects rely on sensory nerve activation, NO-induced hyperemia, vascular endothelial growth factor-stimulated angiogenesis and ghrelin-mediated anti-inflammatory properties (25). The secretion of ghrelin was found to be required to protect gastric mucosa from ROS-mediated injury, but at the same time, the number of gastric X/A-like cells decreased due to severe gastric mucosal lesion caused by the early stage of sepsis and acute pancreatitis $(32,33)$. Ghrelin levels decreased during early stages of sepsis, but the activity of its receptor was elevated in rats (34). In patients with acute pancreatitis, serum levels of ghrelin prior to therapy was lower compared to that during the recovery period (35). In the present study, the levels of ghrelin in serum and gastric tissue were lowest at $12 \mathrm{~h}$ after formation of ANP, and were sustained to $72 \mathrm{~h}$, corresponding to the severity of gastric tissue injury. By contrast, the level of oxidative stress damage and activity of inflammatory factors were increased in the gastric tissue of ANP rats. This indicated that the reduction of endogenous ghrelin in the early stages of ANP may be due to the damage of a number of gastric X/A-like cells. Konturek et al (13) reported that the process of ulcer healing was accelerated by melatonin via induction of ghrelin release, thereby stimulating cell proliferation and promoting mucosal repair in gastric tissue. However, previous studies revealed that exogenous melatonin had little effect on the levels of ghrelin in serum or stomach $(36,37)$. To verify the effect of melatonin on ghrelin induction, the levels of ghrelin in serum and gastric tissue following melatonin treatment were monitored. The results demonstrated that ghrelin levels in the melatonin treatment group recovered during early stages of ANP (first $24 \mathrm{~h}$ ) and continued increasing until $72 \mathrm{~h}$ after formation of ANP. The results of the present study indicate that exogenous melatonin may protect gastric tissue through anti-oxidation and anti-inflammatory activities during the early stage of ANP, while in the advanced stage of ANP, endogenous ghrelin may have a more significant role in the lasting prevention. The role of exogenous melatonin in ANP appears to be a trigger of a self-defense mechanism. Therefore, it is hypothesized that the decrease in ghrelin during the early stages of acute pancreatitis may be due to the damage of gastric X/A-like cells and the recovery of ghrelin secretion following formation of acute pancreatitis, and may rely on the repair of the $\mathrm{X} / \mathrm{A}$ like cells through the machinery of gastric protection. 
In conclusion, the protective effects of melatonin on acute gastric injury during the early stage of ANP may be mediated through anti-oxidative and anti-inflammatory activity, while at the advanced stage of ANP, the lasting prevention effect is likely to be mediated by recovered expression of endogenous ghrelin. Thus, application of gastric mucosal protective agents is required at the early stage of acute pancreatitis.

\section{Acknowledgements}

The present study was supported by the National Natural Science Foundation of China, grant no. 81060043.

\section{References}

1. Shi C, Andersson R, Zhao X and Wang X: Potential role of reactive oxygen species in pancreatitis-associated multiple organ dysfunction. Pancreatology 5: 492-500, 2005.

2. Rau BM, Bothe A, Kron M and Beger HG: Role of early multisystem organ failure as major risk factor for pancreatic infections and death in severe acute pancreatitis. Clin Gastroenterol Hepatol 4: 1053-1061, 2006.

3. Tenner S and Banks PA: Acute pancreatitis: nonsurgical management. World J Surg 21: 143-148, 1997.

4. Zhang JX, Dang SC, Qu JG, Wang XQ and Chen GZ: Changes of gastric and intestinal blood flow, serum phospholipase A2 and interleukin-1beta in rats with acute necrotizing pancreatitis World J Gastroenterol 11: 3578-3581, 2005.

5. Uchikov A, Shopov A and Markova D: Renal complications in severe acute pancreatitis. Khirurgiia (Sofiia) 59: 9-10, 2003 (In Bulgarian).

6. Zhang JX and Dang SC: Ligustrazine alleviates acute lung injury in a rat model of acute necrotizing pancreatitis. Hepatobiliary Pancreat Dis Int 5: 605-609, 2006.

7. Chen TA, Lo GH, Lin CK, et al: Acute pancreatitis-associated acute gastrointestinal mucosal lesions: incidence, characteristics, and clinical significance. J Clin Gastroenterol 41: 630-634, 2007.

8. Dang SC, Zhang JX, Qu JG, Wang XQ and Fan X: Ligustrazine alleviates gastric mucosal injury in a rat model of acute necrotizing pancreatitis. Hepatobiliary Pancreat Dis Int 6: 213-218, 2007.

9. Bubenik GA: Gastrointestinal melatonin: localization, function, and clinical relevance. Dig Dis Sci 47: 2336-2348, 2002.

10. Rodriguez C, Mayo JC, Sainz RM, et al: Regulation of antioxidant enzymes: a significant role for melatonin. J Pineal Res 36: 1-9, 2004

11. Jaworek J, Leja-Szpak A, Bonior J, et al: Protective effect of melatonin and its precursor L-tryptophan on acute pancreatitis induced by caerulein overstimulation or ischemia/reperfusion. J Pineal Res 34: 40-52, 2003.

12. Melchiorri D, Sewerynek E, Reiter RJ, Ortiz GG, Poeggeler B and Nisticò G: Suppressive effect of melatonin administration on ethanol-induced gastroduodenal injury in rats in vivo. Br J Pharmacol 121: 264-270, 1997.

13. Konturek PC, Konturek SJ,Burnat G,Brzozowski T,Brzozowska I and Reiter RJ: Dynamic physiological and molecular changes in gastric ulcer healing achieved by melatonin and its precursor L-tryptophan in rats. J Pineal Res 45: 180-190, 2008.

14. Date Y, Kojima M, Hosoda H, et al: Ghrelin, a novel growth hormone-releasing acylated peptide, is synthesized in a distinct endocrine cell type in the gastrointestinal tracts of rats and humans. Endocrinology 141: 4255-4261, 2000.

15. Brzozowski T, Konturek PC, Drozdowicz D, et al: Role of central and peripheral ghrelin in the mechanism of gastric mucosal defence. Inflammopharmacology 13: 45-62, 2005.
16. Brzozowski T, Konturek PC, Konturek SJ, et al: Exogenous and endogenous ghrelin in gastroprotection against stress-induced gastric damage. Regul Pept 120: 39-51, 2004.

17. Iseri SO, Sener G, Yüksel M, et al: Ghrelin against alendronate-induced gastric damage in rats. J Endocrinol 187: 399-406, 2005.

18. Konturek PC, Brzozowski T, Pajdo R, et al: Ghrelin-a new gastroprotective factor in gastric mucosa. J Physiol Pharmacol 55: 325-336, 2004.

19. El Eter E, Al Tuwaijiri A, Hagar H and Arafa M: In vivo and in vitro antioxidant activity of ghrelin: Attenuation of gastric ischemic injury in the rat. J Gastroenterol Hepatol 22: 1791-1799, 2007.

20. Kusske AM, Rongione AJ, Ashley SW, McFadden DW and Reber HA: Interleukin-10 prevents death in lethal necrotizing pancreatitis in mice. Surgery 120: 284-288; discussion 289, 1996.

21. Lo SK, Leung FW and Guth PH: Protection against absolute-ethanol-induced gastric antral and corpus mucosal injury. A gross and histologic study. Dig Dis Sci 33: 1403-1408, 1988.

22. Placer ZA, Cushman LL and Johnson BC: Estimation of product of lipid peroxidation (malonyl dialdehyde) in biochemical systems. Anal Biochem 16: 359-364, 1966.

23. Bubenik GA, Hacker RR, Brown GM and Bartos L: Melatonin concentrations in the luminal fluid, mucosa, and muscularis of the bovine and porcine gastrointestinal tract. J Pineal Res 26: 56-63, 1999.

24. Suzen S: Recent developments of melatonin related antioxidant compounds. Comb Chem High Throughput Screen 9: 409-419, 2006.

25. Konturek PC, Brzozowski T, Walter B, et al: Ghrelin-induced gastroprotection against ischemia-reperfusion injury involves an activation of sensory afferent nerves and hyperemia mediated by nitric oxide. Eur J Pharmacol 536: 171-181, 2006.

26. Gibbs FP and Vriend J: The half-life of melatonin elimination from rat plasma. Endocrinology 109: 1796-1798, 1981.

27. Brzozowski T,Konturek PC,SliwowskiZ, et al: Prostaglandin/cyclooxygenase pathway in ghrelin-induced gastroprotection against ischemia-reperfusion injury. J Pharmacol Exp Ther 319: 477-487, 2006.

28. Ceranowicz P, Warzecha Z, Dembinski A, et al: Treatment with ghrelin accelerates the healing of acetic acid-induced gastric and duodenal ulcers in rats. J Physiol Pharmacol 60: 87-98, 2009.

29. Sibilia V, Rindi G, Pagani F, et al: Ghrelin protects against ethanol-induced gastric ulcers in rats: studies on the mechanisms of action. Endocrinology 144: 353-359, 2003.

30. Sibilia V, Pagani F, Rindi G, et al: Central ghrelin gastroprotection involves nitric oxide/prostaglandin cross-talk. Br J Pharmacol 154: 688-697, 2008

31. Brzozowski T, Konturek PC, Sliwowski Z, et al: Neural aspects of ghrelin-induced gastroprotection against mucosal injury induced by noxious agents. J Physiol Pharmacol 57 (Suppl 6): 63-76, 2006.

32. Suzuki H, Masaoka T, Hosoda H, et al: Helicobacter pylori infection modifies gastric and plasma ghrelin dynamics in Mongolian gerbils. Gut 53: 187-194, 2004.

33. Suzuki H and Hibi T: Does Helicobacter pylori attack ghrelin-producing cells? J Gastroenterol 40: 437-439, 2005.

34. Wu R, Zhou M, Cui X, Simms HH and Wang P: Ghrelin clearance is reduced at the late stage of polymicrobial sepsis. Int J Mol Med 12: 777-781, 2003.

35. Liu B, Liu X and Tang C: Change of plasma ghrelin level in acute pancreatitis. Pancreatology 6: 531-535, 2006.

36. Canpolat S, Aydin M, Yasar A, Colakoglu N, Yilmaz B and Kelestimur H: Effects of pinealectomy and exogenous melatonin on immunohistochemical ghrelin staining of arcuate nucleus and serum ghrelin levels in the rat. Neurosci Lett 410: 132-136, 2006

37. Aydin M, Canpolat S, Kuloğlu T, Yasar A, Colakoglu N and Kelestimur H: Effects of pinealectomy and exogenous melatonin on ghrelin and peptide YY in gastrointestinal system and neuropeptide $\mathrm{Y}$ in hypothalamic arcuate nucleus: immunohistochemical studies in male rats. Regul Pept 146: 197-203, 2008. 